\title{
Productivity and population diversity of marine organotrophic bacteria in enclosed planktonic ecosystems
}

\author{
M. Laake ${ }^{1 *}$, A. B. Dahle ${ }^{1 * *}$ and G. Hentzschel ${ }^{2}$ \\ ${ }^{1}$ Institute of Microbiology and Plant Physiology, University of Bergen, Allégatan 70, N-5014 Bergen-Universitetet, Norway \\ ${ }^{2}$ Institut für Allgemeine Botanik, Abtlg. für Mikrobiologie, Universität Hamburg, Jungiusstr. 6-8, D-2000 Hamburg 36,
} Federal Republic of Germany

\begin{abstract}
Enclosed ecosystem experiments with marine plankton were carried out in Rosfjord, Norway, March-April, 1979. We report results from studies on planktonic bacteria in natural communities and cultures of phytoplankton contained in 1-m diameter flexible plastic bags, and compare these to observations in the surrounding sea. Emphasis was on organotrophic bacteria and their diversity dynamics, particularly in relation to phytoplankton. Five previously isolated strains of bacteria were followed by immunofluorescent staining on membrane filters, and the populations of chromobacteria, bdellovibrios and luminescent bacteria were assayed by specific methods. Secondary productivity of total bacterial populations was estimated from growth rate measurements in filtered seawater and compared to net primary production. Possibly, as much as one third of the net production was ultimately consumed by the bacteria. The highly dynamic state of organotrophic bacterial populations and diversity in the sea are demonstrated, and the roles of substrate quality and concentrations and of potential bacterial grazers in population regulation are discussed.
\end{abstract}

\section{INTRODUCTION}

Extent and rates of bacterial secondary production in the sea have been a matter of debate for several years (Sorokin, 1971; Overbeck and Daley, 1973; Banse, 1974). Due to the lack of good, direct methods only few reliable data on bacterial secondary production in marine plankton have been reported (Sieburth, 1979); most are limited to measurements of specific growth rates by different methods. Hagström et al. (1979) calculated specific growth rates from measurements of division frequency in bacterial populations from the Baltic Sea under conditions of beginning diatom blooms; they derived a value of $\mu=1.2 \mathrm{~d}^{-1}$ at $15^{\circ} \mathrm{C}$. Fuhrman und Azam (1980) report $\mu=0.63$ to $2.08 \mathrm{~d}^{-1}$ from in situ measurements in the California Bight and in enclosed ecosystems (CEPEX); they estimated that

\footnotetext{
Present addresses:

- Environmental Toxicology Laboratory, Dept. of Pharmacology and Toxicology, Veterinary College of Norway, P.O. Box 8146 Dep., Oslo 1, Norway

- Rogaland Research Institute, P.O.Box 2503, Ullandhaug, $\mathrm{N}-4001$ Stavanger, Norway
}

20 to $25 \%$ of net carbon fixation by photosynthesis was channeled through the bacterial population. In this paper we report measurements of bacterial growth rates by applying several different techniques for population estimates in situ, and estimates of secondary production under conditions of diatom growth in Norwegian coastal waters.

Previously, we have reported the use of immunofluorescent staining of specific strains of organotrophic bacteria on membrane filters in studies of diversity dynamics of natural populations (Dahle and Laake, 1982). In this paper we have used that method on enclosed ecosystems to elucidate interactions of organotrophic bacteria and other groups of organisms in plankton, in particular diatoms. Irrespective of numerous studies it is still important to study the dynamic situation of bacterial production and diversity in the sea in order to achieve a better understanding of the trophodynamic role of organotrophic bacteria. This will require detailed studies in controlled situations, applying sensitive, specific and direct methods for process and population measurements. The use of enclosed ecosystems is a very valuable tool in this regard. 


\section{MATERIALS AND METHODS}

\section{Enumeration of bacteria}

Water samples for bacteriological examination were collected aseptically at 3 and $10 \mathrm{~m}$ depth in $250 \mathrm{ml}$ heat-sterilized bottles with silicone stoppers, filled at sampling depth by snapping off a silicone tubing connecting inflow and outflow glass tubes of different length, designed by $\mathrm{G}$. Hentzschel. Colony-forming units of organotrophs (CFU) were monitored by spread-plate technique on M-65 medium (peptone, tryptone, and yeast extract, $0.5 \mathrm{~g} \mathrm{I}^{-1}$ each [Difco Laboratories], in $200 \mathrm{ml}$ of tap water and $800 \mathrm{ml}$ of aged seawater, with $1.5 \%$ agar); $0.1 \mathrm{ml}$ in triplicate for each sample or dilution. Plates were incubated at $10^{\circ} \mathrm{C}$ for $21 \mathrm{~d}$ before counting to obtain maximum counts (Dahle and Laake, 1982); the coefficient of variation between parallels was generally less than $20 \%$. Characteristic blue-pigmented colonies were tentatively identified as belonging to the genus Chromobacterium.

Samples of $10 \mathrm{ml}$ were preserved with neutralized formaldehyde (final conc. $2 \%$ ) and stored until stained by acridine orange and counted by epifluorescence microscopy (Hobbie et al., 1977), using a Leitz Wetzlar Orthoplan microscope with Ploemopak filter system. I and a $67 \mathrm{X}$ oil immersion objective. BY counting a

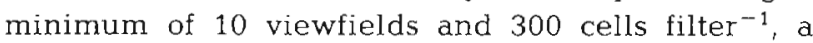

coefficient of variation of $4 \%$ between parallels was achieved. The counts are designated acridine orange total counts, or AOTC.

Samples of $100 \mathrm{ml}$ were similarily preserved for immunofluorescent specific total counts (ISTC) of 5 strains of organotrophic bacteria isolated from Norwegian coastal water (Dahle and Laake, 1982). These isolates had previously been characterized to the genus level (Dahle, cand. real thesis, Univ. Bergen, 1979), as summarized in Table 1. Vaccine produced from cultivation of the isolates and injected in rabbits produced specific antisera (Dahle and Laake, 1982). Following fixation with formaldehyde and filtration on black Uni-Pore polycarbonate membranes $(0.2$ or $0.4 \mu \mathrm{m}$ póre-size) as for AOTC, bacteria on the filter were exposed to one of the 5 alternative anti-sera and specific antibodies allowed to adhere to the cell sur faces. Following washing with saline phosphate buffer a fluorescein isothiocyanate-conjugated swine-antirabbit IgG was added (DAKO Immunoglobulins, Ltd.), which binds to the rabbit antibodies at the cell surfaces. Positive bacteria were then identified and counted by fluorescent microscopy as done with the acridine orange stained filters. One filtration of $20 \mathrm{ml}$ sample ${ }^{-1}$ and counting a minimum of 10 fields of view and 150 cells consistently gave a coefficient of variation of $16 \%$ between parallels at $10^{7}$ or more cells $\mathrm{dm}^{-3}$, increasing to $55 \%$ at $10^{6}$ cells $\mathrm{dm}^{-3}$. The latter density was consequently chosen as the limit of quan-

Table 1. Characteristic properties of the 5 isolated strains used for immunofluorescent assay on membrane filters, when grown on M-65 medium (see text for medium composition)

\begin{tabular}{|c|c|c|c|c|c|}
\hline $\begin{array}{l}\text { Strain: } \\
\text { Genus }\end{array}$ & $\begin{array}{c}9 \\
\text { Aeromonas } \\
\text { sp. }\end{array}$ & $\begin{array}{c}13 \\
\text { Chromobacterium } \\
\text { cf. lividum }\end{array}$ & $\begin{array}{c}16 \\
\text { Pseudomonas } \\
\text { sp. }\end{array}$ & $\begin{array}{l}20 \\
\text { Vibrio } \\
\text { sp. }\end{array}$ & $\begin{array}{c}28 \\
\text { Pseudomonas } \\
\text { sp. }\end{array}$ \\
\hline Cell morphology & Bent rod & Rod & Small rod & Bent rod, chains & Bent rod, pleomorph \\
\hline Dimensions ( $\mu \mathrm{m})$ & $0.5 \times 0.8-1.3$ & $0.5 \times 1.7$ & $0.4 \times 0.6-1.0$ & $0.7 \times 1.5$ & $0.5 \times 1$ \\
\hline Gram-reaction & - & - & - & - & - \\
\hline Denitrification & + & - & - & + & - \\
\hline Metabolism & fermentative & oxidative & oxidative & fermentative & oxidative \\
\hline Temperature optima & $23^{\circ} \mathrm{C}$ & $18^{\circ} \mathrm{C}$ & $23^{\circ} \mathrm{C}$ & $24^{\circ} \mathrm{C}$ & $27^{\circ} \mathrm{C}$ \\
\hline Salinity tolerance & $5-75 \%$ & $20-35 \%$ & $10-75 \%$ & $5-75 \%$ & $5-100 \%$ \\
\hline \multicolumn{6}{|l|}{ Growth on: } \\
\hline peptone & + & + & $(+)$ & t & + \\
\hline casamino acids & + & + & + & + & $(+)$ \\
\hline glycollate & $(+)$ & -- & - & + & + \\
\hline acetate & - & + & + & - & + \\
\hline glycerol & + & - & - & + & + \\
\hline mannitol & $(+)$ & $(+\cdot)$ & + & - & + \\
\hline glucose & + & + & + & + & + \\
\hline arginin & + & - & - & + & - \\
\hline citrate & + & - & - & + & - \\
\hline lactate & - & - & - & - & + \\
\hline
\end{tabular}


tification in seawater samples, as indicated by a dotted line in the relevant figures.

The presence of bacteriolytic bacteria (Bdellovibrio, Myxobacterium) was tested for by enrichment cultures and enumerated by a plaque assay (Hentzschel, 1978, 1980) with 5 organotrophic marine bacteria as prospective hosts and Pseudomonas doudoroffii as standard host. Sterile water samples were divided into 12 subsamples of $50 \mathrm{ml}$ each, one of the host bacteria added to a final concentration of approximately $10^{8}$ cells $\mathrm{ml}^{-1}$, and the samples incubated on a shaker (200 r.p.m., $16^{\circ} \mathrm{C}$ ) for $1 \mathrm{wk}$. Enumerations of bacteriolytic bacteria were carried out on unfiltered and prefiltered $(0.45 \mu \mathrm{m})$ enrichments by spreading a $1 \mathrm{ml}$ subsample on double-layer soft agar containing one of the host bacteria as substrate, and plaques counted following incubation. Subsamples of $1 \mathrm{ml}$ seawater were also enumerated directly without previous enrichment.

\section{Physical conditions}

The water masses in Rosfjord were not very stable, as described in detail by Brockmann et al. (1981). There were 2 phases with saline upwelling water $\left(5\right.$ to $6{ }^{\circ} \mathrm{C}$ ) and 2 phases with cold, less saline water from the Skagerrak $\left(1\right.$ to $2{ }^{\circ} \mathrm{C}$ ) coming into the fjord. A major inflow of surface water from Skagerrak occurred on March 12 ; consequently the prevailing pre-bloom condition with high nutrient concentrations and low biomass rapidly shifted to a descending bloom condition with high biomass and low concentrations of nutrients. Nitrate concentrations changed from 9 to $11 \mu \mathrm{g}$ at $\mathrm{N} \mathrm{dm}{ }^{-3}$ to less than $1 \mu \mathrm{g}$-at $\mathrm{N} \mathrm{dm}{ }^{-3}$, while chlorophyll increased to more than $9 \mu \mathrm{g} \mathrm{dm} \mathrm{dm}^{-3}$. The corresponding primary productivity was 2 to $3 \mu \mathrm{g} \mathrm{C}$ $\mathrm{dm}^{-3} \mathrm{~h}^{-1}$. Daily incident light intensity (395 to $720 \mathrm{~nm}$ ) at $5 \mathrm{~m}$ depth varied from $8 \mathrm{E} \mathrm{m}^{-2}$ on cloudy days to $16 \mathrm{E} \mathrm{m}^{-2}$ on sunny days (Dahl et al., 1983).

\section{Field sampling and experiments}

Water samples were collected once a day from the 4 systems studied. The fjord was sampled at the site of experiments from March 6 until April 4, 1979 (Brockmann et al., 1981). Flexible plastic bags were filled at site with an undisturbed water column or pre-filtered water. They were of $1 \mathrm{~m}$ diameter and variable depth, supported by floating frames, open at the surface and closed in the bottom, and with polyethylene inner walls (Brockmann et al., 1974). A 13 m deep natural (unamended) bag was sampled from March 7 until April 4 (Dahl et al., 1983), while 2 culture bags were sampled from March 18 until April 5 (Eberlein et al., 1983; Jahnke et al., 1983). These were $20 \mathrm{~m}$ deep and filled with prefiltered seawater from approximately $5 \mathrm{~m}$ depth in the sea, and were re-inoculated with cultures of Skeletonema costatum and Thalassiosira nordenskiöldii, respectively, isolated from the fjord. Later both bags were also re-inoculated with the 5 ISTC strains (Table 1) by pumping through a silicone tubing lifted at a prefixed rate through the water column. The populations found óne day after inoculation in the 2 bags are compared to theoretical densities, assuming no growth, in Table 2 .

\section{Calculation of diversity index}

A simple diversity index was calculated according to Dahle and Laake (1982), as:

$$
\mathrm{n}_{\text {AOTC }}=\frac{\text { AOTC }}{\sum_{n=1}^{\mathrm{i}} \text { ISTC }} \mathrm{n}_{\mathrm{ISTC}}
$$

Diversity is defined as the number of serologically different strains present in the AOTC population $\left(\mathrm{n}_{\text {AOTC }}\right)$ when $\mathrm{n}_{\text {ISTC }}$ is the number of ISTC strains tested for.

Table 2. Actual and theoretical densities of ISTC strains $1 \mathrm{~d}$ after re-inoculation in culture bags $\left(10^{7}\right.$ cells $\left.1^{-1}\right)$. Coefficient of variance between parallels: $16 \%$

\begin{tabular}{|c|c|c|c|c|c|c|}
\hline \multirow[b]{2}{*}{ Strain: } & \multirow[b]{2}{*}{ Depth: } & \multicolumn{2}{|c|}{$\begin{array}{l}\text { Skeletonema } \\
\text { culture }\end{array}$} & \multicolumn{2}{|c|}{$\begin{array}{l}\text { Thalassiosira } \\
\text { culture }\end{array}$} & \multirow[t]{2}{*}{$\begin{array}{l}\text { Theoretical } \\
\text { density }\end{array}$} \\
\hline & & $3 \mathrm{~m}$ & $10 \mathrm{~m}$ & $3 \mathrm{~m}$ & $10 \mathrm{~m}$ & \\
\hline 9 & & 4.2 & 3.8 & 2.9 & 2.7 & 3.3 \\
\hline 13 & & 1.9 & 2.5 & 2.1 & 2.1 & 1.0 \\
\hline 16 & & 3.5 & 1.9 & 2.6 & 2.5 & 0.3 \\
\hline 20 & & 3.7 & 2.4 & 2.4 & 2.6 & 3.8 \\
\hline 28 & & 1.5 & 1.3 & 1.5 & 2.0 & 6.7 \\
\hline
\end{tabular}




\section{RESULTS}

\section{Dynamics of bacterial populations}

The diversity dynamics of organotrophs in the surrounding water has been reported by Dahle and Laake (1982). The succession of the 5 immunospecific strains showed a good correlation to the colony-forming organotrophs (CFU). The influx of low salinity surface water increased the CFU population 10-fold, and also the ISTC similarly. The sum of ISTC relative to AOTC increased from $0.76 \%$ and $1.28 \%$ at 3 and $10 \mathrm{~m}$, respectively, on March 10 , to $1.47 \%$ and $2.13 \%$ on March 18.

The natural bag was filled with high-salinity water with low biomass and high concentrations of nutrients on March 7, and a bloom of diatoms slowly developed (Dahl et al., 1983). The AOTC population (Fig. 1) increased from $6 \times 10^{8}$ cells $i^{-1}$ to $2 \times 10^{9}$ cells $1^{-1}$ during the first $2 \mathrm{wk}$, and then stabilized at this level. The CFU increased 10 -fold, from $10^{6}$ colonies $1^{-1}$ to $10^{7}$ colonies $1^{-1}$; numbers at $3 \mathrm{~m}$ depth were commonly higher than at $10 \mathrm{~m}$ depth.

At $3 \mathrm{~m}$ depth isolates no. 9, 13 and 16 increased

AOTC $\mathrm{I}^{-1}$
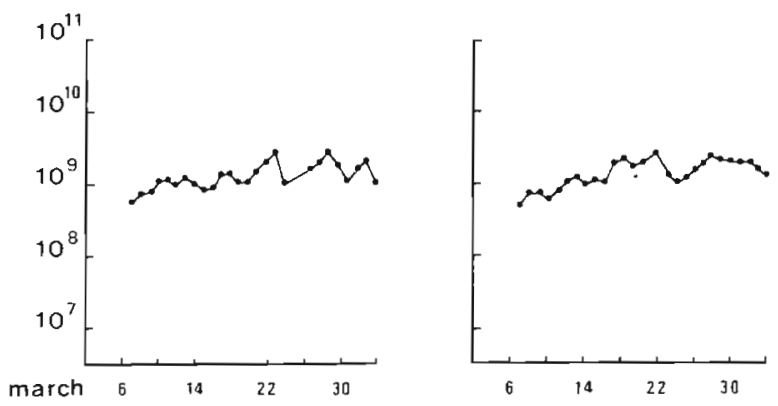

$3 \mathrm{~m}$

$10 \mathrm{~m}$
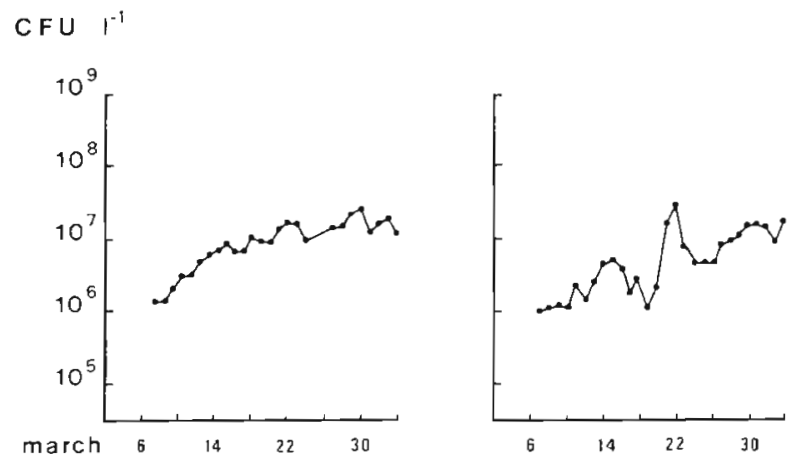

Fig. 1. Total bacterial populations (AOTC) and colony-forming organotrophic bacteria (CFU) in natural bag. AOTC was determined by epifluorescence microscopy on acridine orange-stained polycarbonate filters, and CFU by spreadplate technique on M-65 medium (see text for details) rapidly 1 or 2 orders of magnitude in $3 \mathrm{~d}$, and then stabilized at slightly higher population densities than usually found in the fjord (Fig. 2). Isolates no. 20 and 28 grew more slowly 1 order of magnitude in $11 \mathrm{~d}$. At $10 \mathrm{~m}$ depth the tendencies were the same, although with larger variations. The gradual increase in CFU at $3 \mathrm{~m}$ depth coincided with an increase in net photosynthesis (Dahl et al., 1983). Isolates no. 20 (Vibrio) and no. 28 (Pseudomonas) followed the same trend, while the sudden increase observed with the other isolates is not readily explained from chemical or biological data.

The 2 culture bags with monocultures of Skeletonema costatum and Thalassiosira nordenskiöldii (Eberlein et al., 1983; Jahnke et al., 1983) showed a remarkable parallel development with respect to bacterial populations, in AOTC and CFU (Fig. 3), and in ISTC (Fig. 4), and at both sampling depths. The AOTC population reached a maximum of $2 \times 10^{9}$ cells $l^{-1}$ in the culture bags, and the CFU population of $3 \times 10^{7}$ colonies $1^{-1}$. CFU data showed an interesting peak on March 28 in both bags and at both sampling depths with doubling of colony counts, and which particulary in one bag (Fig. $3 \mathrm{~B}$ ) developed when the AOTC were already decreasing. In some cases the ISTC strains also peaked coincidentally, and in general these strains developed very similarly to the CFU.

Specific counts for all strains developed remarkably parallel, considering the 2 independent experiments and the 2 different depths sampled (Fig. 4). All strains were present and in rapid growth at the day of reinoculation, which was not expected; this makes it difficult to assess the effects of re-inoculation on further development (Table 2). The number of bluepigmented colonies on M-65 medium, tentatively identified as Chromobacterium spp., can be interpreted as the maximum number of colonies possibly formed by the strain no. 13 (Cromobacterium cf. lividum). By comparison the counts of the blue-pigmented colonies seem very well correlated to ISTC of isolate no. 13 , but at only $1 \%$ of its population level (Fig. 5).

We were not able to demonstrate any Bdellovibrios in enrichments or directly in seawater. Myxobacterium was in rare cases present in the enrichments. Protozoa (flagellates, amoeba, ciliates) were, however, observed in the enrichments, and also caused plaques on softagar directly from seawater. Luminescent bacteria, on the other hand, accounted for a small but significant portion of the colony-forming organotrophs.

\section{Diversity indices}

As discussed by Dahle and Laake (1982), the diversity of organotrophic bacterial populations showed a 
ISTC I -1 $^{-1}$

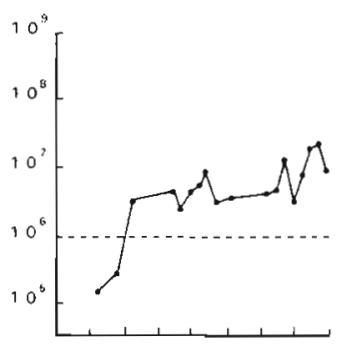

STRAIN

9

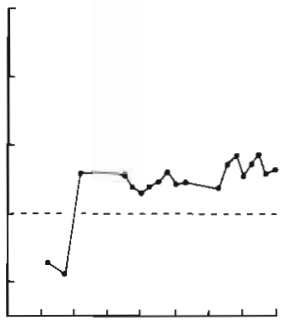

13

ISTC $\left.\right|^{-1}$
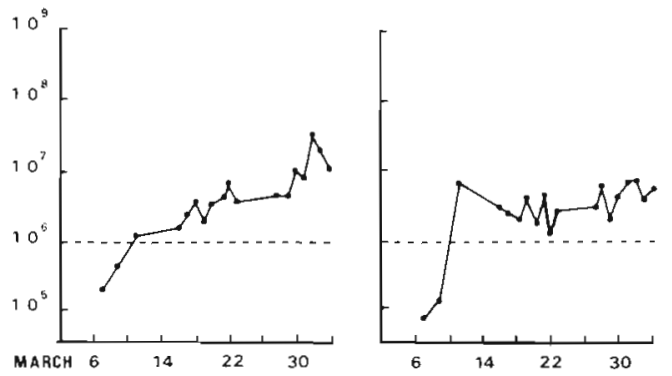

$3 \mathrm{~m}$
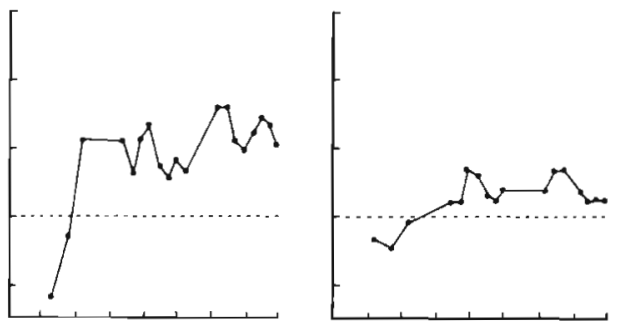

20

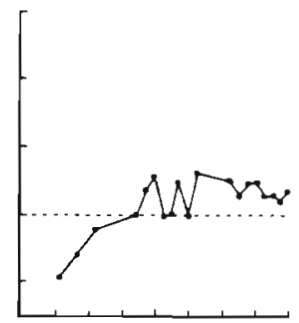

28

Fig. 2. Populations of specific organotrophic bacteria (ISTC) in natural bag. Specific counts obtained by epifluorescence microscopy and immunofluorescent staining by the use of specific rabbit antisera. Dotted line: cell density below which the coefficient of variation increased from the normal 16 to $55 \%$

A OTC I $^{-1}$
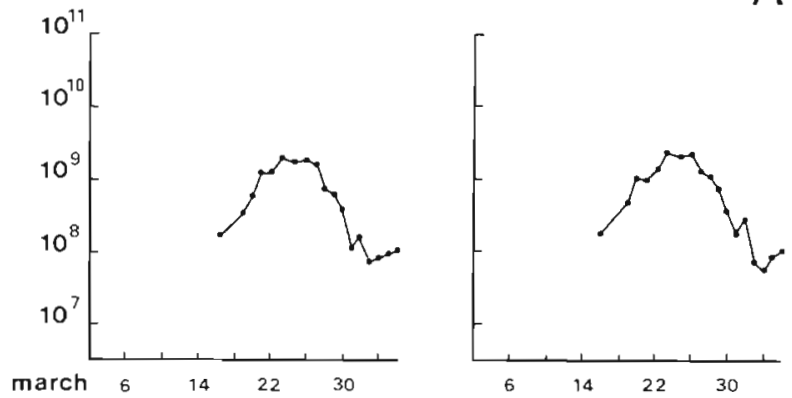

A

$\mathrm{B}$

$3 \mathrm{~m}$

$10 \mathrm{~m}$
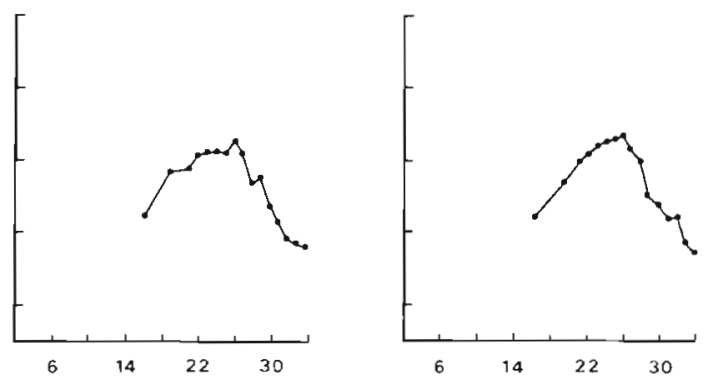

$3 \mathrm{~m}$

$10 \mathrm{~m}$
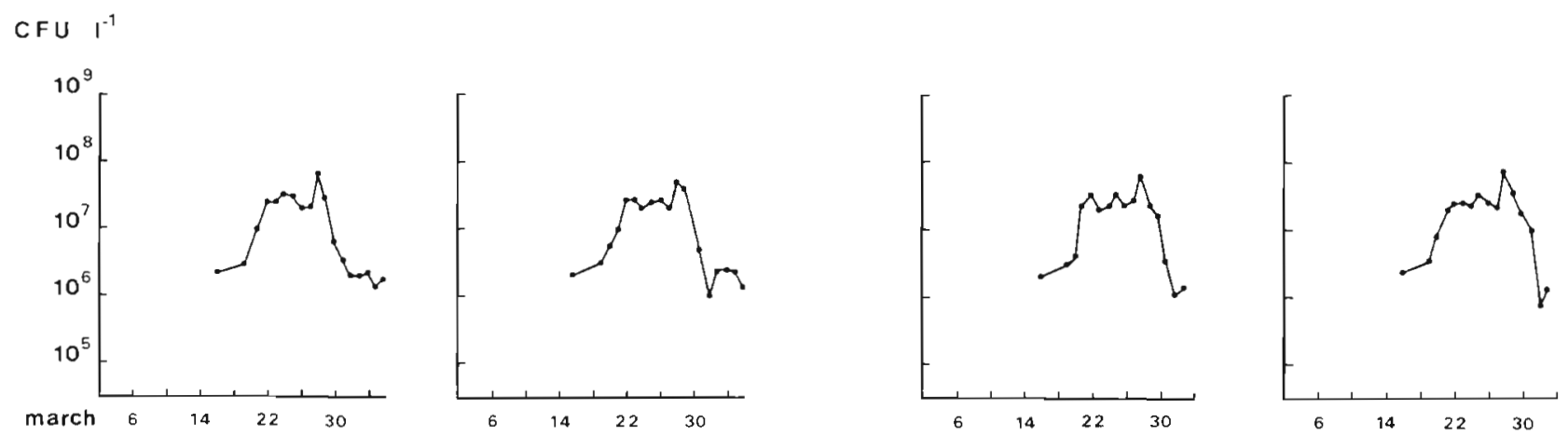

Fig. 3. Total bacterial populations (AOTC) and colony-forming organotrophic bacteria (CFU) in the culture bags with (A) Skeletonema costatum, and (B) Thalassiosira nordenskiöldii. AOTC determined by acridine orange staining and epifluorescence microscopy, and CFU by spread-plate technique on M-65 medium 
ISTC I"

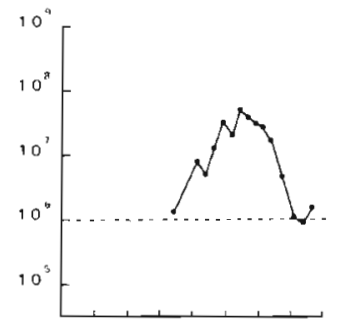

STRAIN

9

ISTC $1^{-1}$

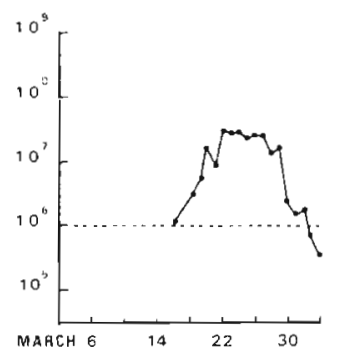

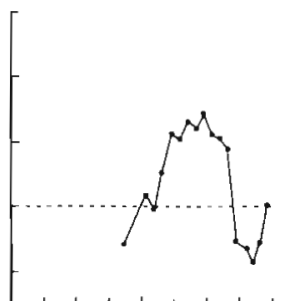

13

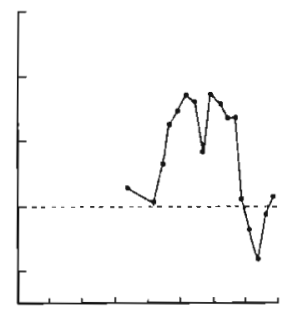

16

$10 \mathrm{~m}$
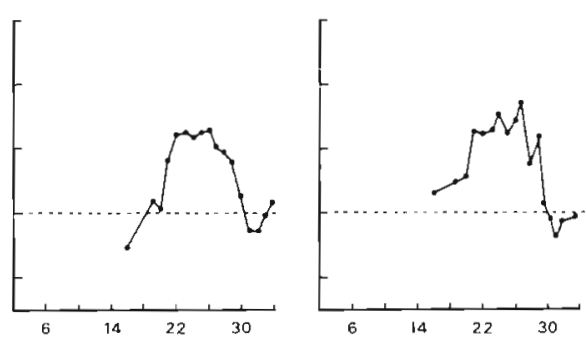

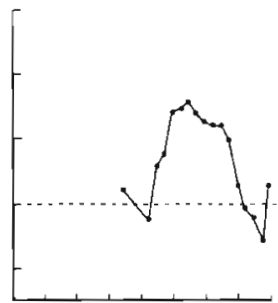

20
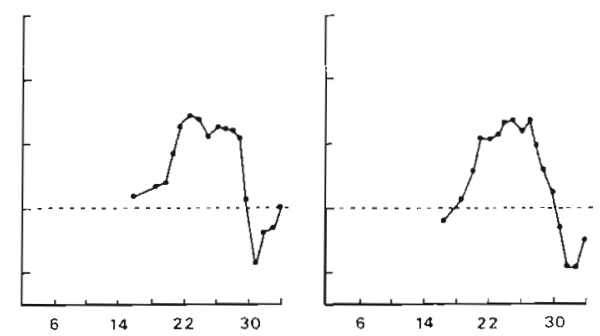

B
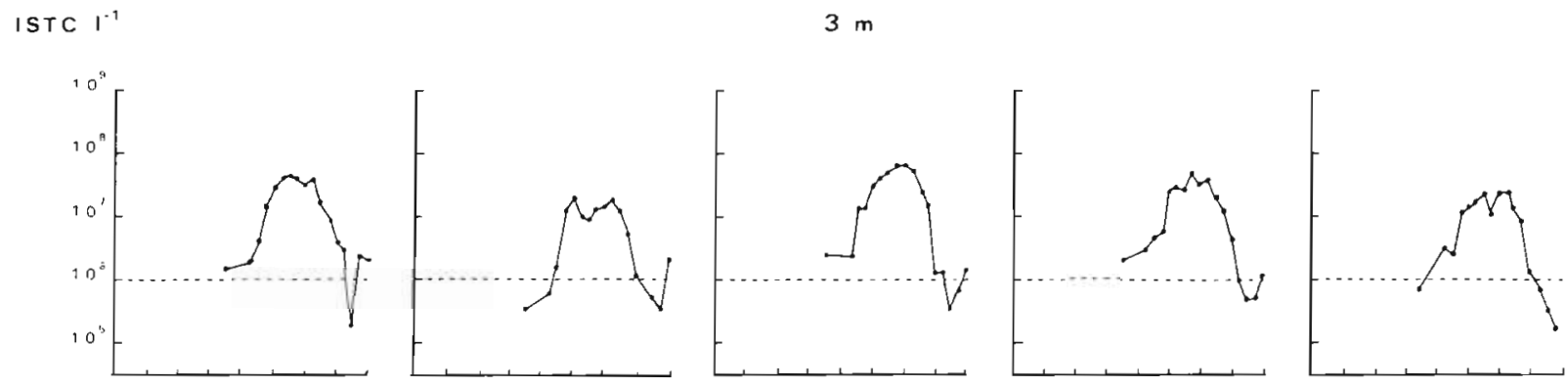

STRAIN

9

13

16

20

28

ISTC $\left.\right|^{-1}$

$10 \mathrm{~m}$
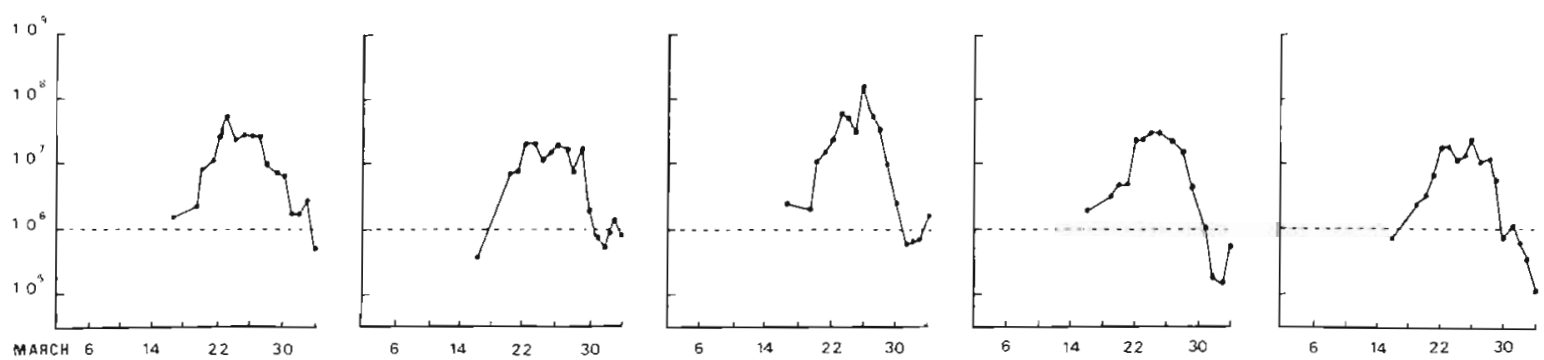

Fig. 4. Populations of specific organotrophic bacteria (ISTC) in culture bags with (A) Skeletonema costatum, and (B) Thalassiosira nordenskioldii. Specific counts obtained by indirect immunofluorescent staining by the use of specific rabbit antisera. Dotted line: cell density below which the coefficient of variation increased from the normal 16 to $55 \%$ 

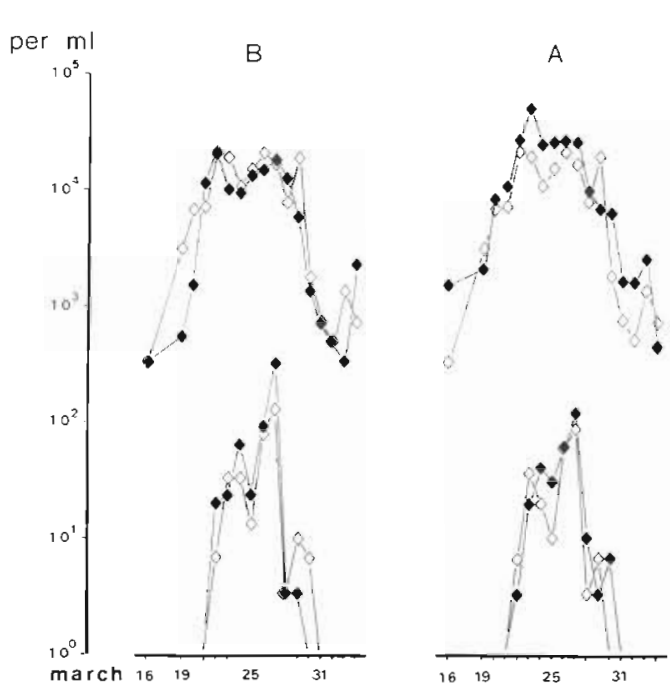

Fig. 5. Plate counts tentative Chromobacterium spp., registered as blue-pigmented colonies on M-65 medium, compared to specific counts (ISTC) of Strain 13, Chromobacterium cf. lividum. Open symbols: $3 \mathrm{~m}$ depth; closed symbols: $10 \mathrm{~m}$ depth in Culture Bags A and B (see Fig. 4)

significant reduction with the intrusion of low-salinity, high-biomass surface water from the Skagerrak. To a lesser extent, a similar reduction in diversity was observed in the natural bag during the first 4 to $6 \mathrm{~d}$ (Fig. 6C) as the net primary production increased (Dahl et al., 1983), and then stabilized at a low level. In the culture bags the diversity was generally low and was further reduced when the populations regained following the prefiltration (Fig. 6 A, B).

\section{Bacterial growth rates}

The culture experiments allow for realistic estimates of bacterial growth rates in situ at ambient substrate concentrations. Grazing can be neglected in the first period of growth observed, as the populations of flagellates at that time were very low. In Table 3 specific growth rates have been calculated for the different populations in question, and for the ISTC strains compared to values obtained in culture. There are no noticeable differences encountered between the 2 bags, nor between 3 and $10 \mathrm{~m}$ depths. Strain 16 (Pseudomonas) grew slightly faster than the others, and Strain 9 (Aeromonas) slightly slower, but the differences are small and probably insignificant. The corresponding doubling times averaged from 0.4 to $0.6 \mathrm{~d}$ for the different strains. In comparison the AOTC population grew much slower, with doubling times ranging from 0.8 to $1.4 \mathrm{~d}$.

The water temperature during the exponential

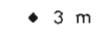

(c) $10 \mathrm{~m}$

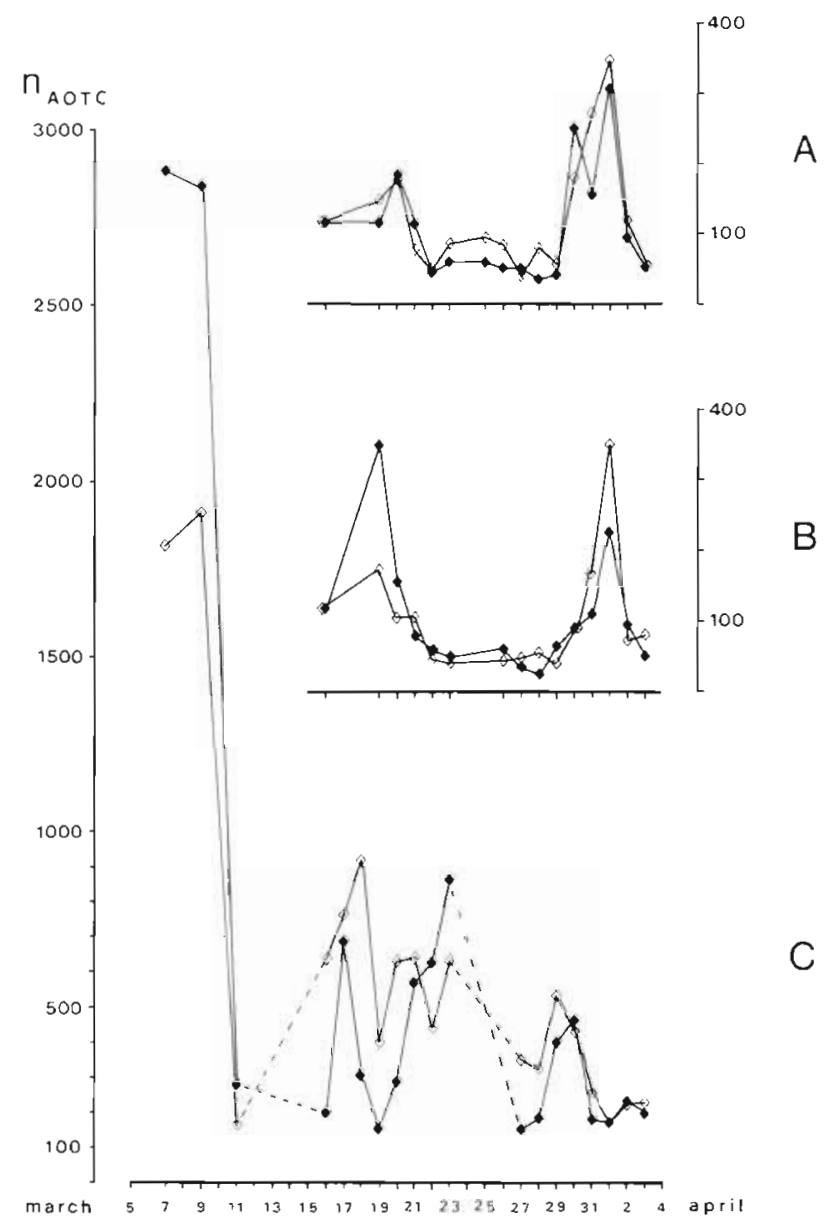

Fig. 6. Diversity indices in culture bags with (A) Skeletonema costatum, and (B) Thalassiosira nordenskiöldii, and in natural bag (C). $n_{A O T C}$ : theoretical number $(n)$ of serologically different strains in the total (AOTC) population (see text for calculation)

growth phase was only 1 to $2{ }^{\circ} \mathrm{C}$, which explains the very slow growth rates observed. In pure culture the isolates followed the Arrhenius' temperature relation very nicely from optimal temperatures down to $5^{\circ} \mathrm{C}$, which was the lowest temperature tested (A. B. Dahle, cand. real thesis, University of Bergen, 1979). At this temperature maximum specific growth rates ranged from 3.2 to $4.1 \mathrm{~d}^{-1}$, except for Strain 16, which grew very well in situ, but obviously was inhibited by laboratory growth conditions. $\mathrm{A}_{10}$ of 2.3 to 2.6 in the 5 to $15^{\circ} \mathrm{C}$ interval was calculated from culture data, equivalent to temperature coefficients of 1,100 and $1,087 \mathrm{grad}^{-1}$, respectively. Assuming that this temperature relationship is valid also below $5^{\circ} \mathrm{C}$, the measured growth rates at $2{ }^{\circ} \mathrm{C}$ in situ represent 40 to $57 \%$ of the theoretical maximum (Table 3 ). 
Table 3. Measured specific growth rates in situ for ISTC strains, CFU population and AOTC population in prefiltered seawater contained in plastic bags, compared to maximum specific growth rates of the ISTC strains in culture

\begin{tabular}{|c|c|c|c|c|c|c|c|c|c|c|c|c|c|c|c|}
\hline & \multirow{3}{*}{$\begin{array}{l}\text { Strain: } \\
\text { Depth: }\end{array}$} & \multicolumn{2}{|c|}{ Aeromonas } & \multirow{2}{*}{\multicolumn{2}{|c|}{$\begin{array}{c}\text { Chromobacterium } \\
\text { cf. Jividum } \\
13\end{array}$}} & \multicolumn{2}{|c|}{ Pseudomonas } & \multicolumn{2}{|c|}{ Vibrio } & \multicolumn{2}{|c|}{ Pseudomonas } & \multicolumn{2}{|c|}{ CFU } & \multirow{2}{*}{\multicolumn{2}{|c|}{ AOTC }} \\
\hline & & \multicolumn{2}{|c|}{9} & & & \multicolumn{2}{|c|}{16} & \multicolumn{2}{|c|}{20} & \multicolumn{2}{|c|}{28} & \multirow{2}{*}{\multicolumn{2}{|c|}{$3 \mathrm{~m} 10 \mathrm{~m}$}} & & \\
\hline & & $3 \mathrm{~m}$ & $10 \mathrm{~m}$ & $3 \mathrm{~m}$ & $10 \mathrm{~m}$ & $3 m$ & $10 \mathrm{~m}$ & $3 \mathrm{~m}$ & $10 \mathrm{~m}$ & $3 m$ & $10 \mathrm{~m}$ & & & $3 \mathrm{~m}$ & $10 \mathrm{~m}$ \\
\hline In situ & Bag A & 0.97 & 1.17 & 1.35 & 1.45 & 1.38 & 1.70 & 1.31 & 1.00 & 1.68 & 1.02 & 0.97 & 0.99 & 0.60 & 0.85 \\
\hline experiments & Bag B & 1.22 & 1.38 & 2.02 & 1.11 & 1.75 & 1.84 & 1.47 & 1.68 & 1.45 & 1.08 & 1.66 & 0.90 & 0.48 & 0.48 \\
\hline$\mu, \mathrm{d}^{-1}$ & Mean & \multicolumn{2}{|c|}{1.19} & \multicolumn{2}{|c|}{1.48} & \multicolumn{2}{|c|}{1.67} & \multicolumn{2}{|c|}{1.37} & \multicolumn{2}{|c|}{1.31} & \multicolumn{2}{|c|}{1.13} & \multicolumn{2}{|c|}{0.60} \\
\hline Laboratory & Opt. terap. & \multicolumn{2}{|c|}{9.48} & \multicolumn{2}{|c|}{7.08} & \multicolumn{2}{|c|}{$0.6^{\cdots}$} & \multicolumn{2}{|c|}{8.04} & \multicolumn{2}{|c|}{9.12} & \multicolumn{2}{|c|}{-} & \multicolumn{2}{|c|}{ - } \\
\hline experiments & $5^{\circ} \mathrm{C}$ & \multicolumn{2}{|c|}{3.91} & \multicolumn{2}{|c|}{3.60} & \multicolumn{2}{|c|}{0.10} & \multicolumn{2}{|c|}{3.19} & \multicolumn{2}{|c|}{4.08} & \multicolumn{2}{|c|}{-} & \multicolumn{2}{|c|}{ - } \\
\hline$\mu_{\max }, d^{-1}$ & $2{ }^{\circ} \mathrm{C}$ & 2.5 & 94 & 2.3 & 71 & - & - & & 40 & & 06 & & - & & - \\
\hline $\begin{array}{l}\text { In situ as } \% \\
\text { of theoretical } \\
H_{\max }\end{array}$ & & 4 & 0 & 5 & 5 & - & - & 5 & 7 & & 3 & & - & & - \\
\hline $\begin{array}{l}\text { - Growth on } \\
\text { temperatur } \\
\text { - Iaboratory }\end{array}$ & $\begin{array}{l}\text { M-65 seaw } \\
\text { re constant } \\
\text { growth rat }\end{array}$ & $\begin{array}{l}\text { fer me } \\
\text { f } 1.1 \mathrm{~g} \\
\mathrm{~s} \text { for } \mathrm{S}\end{array}$ & $\begin{array}{l}\text { edium } \\
\operatorname{rrad}^{-1} \mathrm{i} \\
\operatorname{train} 1\end{array}$ & $\begin{array}{l}\text { flask cu } \\
\text { the Arrh } \\
\text { are not c }\end{array}$ & $\begin{array}{l}\text { Itures in th } \\
\text { enius rela } \\
\text { orrect due }\end{array}$ & $\begin{array}{l}\text { labor } \\
\text { on } \\
\text { o inhil }\end{array}$ & $\begin{array}{l}\text { atory. V } \\
\text { itory } g\end{array}$ & $\begin{array}{l}\text { We fo } \\
\text { wth } \mathrm{C}\end{array}$ & $2{ }^{\circ} \mathrm{C}$ & culate & from & ue at & $5^{\circ} \mathrm{CH}$ & & ying a \\
\hline
\end{tabular}

\section{Estimated bacterial production}

By assuming similar growth rates in the fjord and in the natural bag as in the culture bags and knowing the bacterial total population it is possible roughly to estimate bacterial biomass by conversion factors, calculate secondary biomass production by bacteria and compare this with photosynthesis. This has been done for a steady-state situation in the natural bag and a hydrodynamically stable situation in the fjord on March 23. An average cell volume of $0.1 \mu \mathrm{m}^{3}$ was chosen (Laake et al., 1983), and marine bacteria assumed to contain $1.2110^{-7} \mu \mathrm{g} \mathrm{C} \mu \mathrm{m}^{-3}$ cell volume (Watson et al., 1977). Assuming a conversion efficiency of $30 \%$ from organic substrate to bacterial biomass (Bell and Sakshaug, 1980), the consumption of organic carbon needed for the secondary bacterial production may also be estimated.

Bacterial biomass produced in the sea and in the natural bag, respectively, amounted to 0.67 to $0.91 \mu \mathrm{g}$ $\mathrm{C}^{-1} \mathrm{~h}^{-1}$, which was 12 to $15 \%$ of net photosynthesis on March 23. If steady states are assumed, an estimated 35 to $45 \%$ of the carbon fixed by photosynthesis was consequently chanelled through the bacterial population.

\section{DISCUSSION}

The predominance of Gram-negative bacteria among the 34 isolated strains, out of which $5 \mathrm{G}$-strains were selected for this study (Table 1), confirm observations made by earlier investigators (e.g. Sieburth, 1979). All strains were present in significant numbers in all samples, which by itself is quite remarkable. As they were rapidly growing at the date of re-inoculation into the culture bags, the significance of re-inoculation to the later development is difficult to judge (Table 2). However, after $10 \mathrm{~d}$ the 5 ISTC strains accounted for 8.1 and $11.3 \%$ of AOTC at 3 and $10 \mathrm{~m}$ depth, respectively, in the Skeletonema culture, and this is substantially higher than in the natural bag, where the figure was about $1 \%$. It seems unlikely that this was the effect of re-inoculation only, since deviations from theoretical density $1 \mathrm{~d}$ later vary unsystematically and suggest a substantial die-off or prolonged lag-phase for inoculated cells when transferred from culture conditions (Table 2). In conclusion, re-inoculation is believed to have been of little significance to measured growth rates (Table 3) and final cell densities.

As pointed out by many earlier investigators, only a small fraction of the total population of organotrophs present in seawater is able to form colonies on solid media. In this study the ratio of CFU to AOTC was approximately $1: 100$ in the natural bag (Fig. 1), but CFU increased slightly more with time as the production increased, while AOTC varied between rather narrow limits. This supports our argument that CFU may be a better index of active bacteria and respond more clearly to increased substrate levels, i.e. when oil is added to the sea surface (Dahl et al., 1983). The ratio of blue-pigmented colonies relative to Strain 13 (Chromobacterium) was also approximately 1:100 (Fig. 5), and the sum of ITSC usually was equal to or exceeded CFU even in the sea samples (Dahle and Laake, 1982) and by far exceeded CFU in the culture bags (Fig. 3 and 4 ).

Sieburth (1979) suggested that 2 classes of marine bacteria exist in plankton: true planktobacteria, normally freeswimming, prevail at low substrate conditions and are not able to grow on solid media, and 
epibacteria, normally attached to detrital particles, require high substrate concentrations and dominate in plate counts. The ISTC strains may, according to this scheme, be classified as epibacteria, since they were all isolated on a nutrient-rich agar medium. But they were still poorly represented in the CFU data, and were predominantly observed as free cells on the membrane filters, as were also the rest of the AOTC population. These observations do not support a schematic classification as suggested by Sieburth (1979), although some species undoubtly have selective advantages for growth on plates. It seems more likely that in general the state of growth and cell division of the individual bacterium determine its ability to survive and grow on solid media. Within a certain population only ca. $10 \%$ of the cells present in plankton normally seem to be in the appropriate physiological state.

The ISTC strains did not show any stimulatory or inhibitory reactions to, or specific associations with, for example the growth of a particular algae, as previously described from dense cultures (e.g. Bell et al., 1974). Although these phenomena may exist in nature, they are probably not very significant in controlling bacterial growth conditions in the sea at the species level. Unselective mechanisms seem to be of more importance, as judged from the conformity of all population developments in the culture bags (Fig. 3 and 4). Evidently the presence of slowly growing diatoms had only negligible effects on growth and decline of bacterial populations within the time-scale of our observations. The rapid growth observed must have been due to the growth of organotrophs consuming the substrates present in the seawater or made available through the prefiltration procedure, while the rapid decline following a short stationary phase may have been caused by grazing protozoans (Eberlein et al,, 1983; Laake et al., 1983). The ISTC strains may, however, be classified as zymogenous species, which predominate relative to others in periods of high substrate availability, which would also be expected from their isolation on a nutrient-rich medium (Dahle and Laake, 1982). Thus they are generally stimulated by algal biomass increase or photosynthesis, as evident from Fig. 2 and $6 \mathrm{C}$.

The AOTC in the fjord and in the natural bag (Fig. 1)

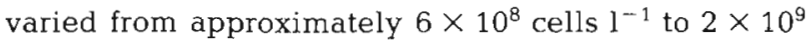
cells $l^{-1}$, in very good agreement with recent population estimates of marine bacteria in this climatic region (Hagström et al., 1979; Meyer-Reil et al., 1979). The observed maxima correspond with the maxima recorded in the culture bags (Fig. 4), where further growth most likely was supressed by heavy flagellate grazing (Laake et al., 1983). This favours the theory that the upper level of the total bacterial population in plankton is regulated by density-dependent grazing by protozoans, primarily phagotrophic nanoflagellates with high maximal growth rates (Sieburth, 1979). Some very low cell densities were observed in the culture bag when large populations of flagellates were allowed to build up and over-graze their bacterial food supply. AOTC were then reduced to $8 \times 10^{7}$ cells $1^{-1}$, or $1.3 \%$ of the minimum observed in other systems (Eberlein et al., 1983). This may represent a threshold value for energetically efficient flagellate grazing (Laake et al., 1983).

On the other hand, organotrophic bacteria will tend to maximize their numbers to achieve the highest possible potential for substrate consumption. The measured growth rates (Table 3) indicate that concentrations of the dominant carbon and energy sources were at or near to half-saturation levels for growth, when compared to the theoretical maximum growth rates at those temperatures. At even lower substrate concentrations, which frequently may be the case in steady state situations, a large fraction of the cells may move into dormancy through substrate-dependent metabolic regulation. This may explain why the total population rarely will be reduced below some threshold level for energetically efficient grazing by protozoans, except in long periods of starvation, and also why a large fraction of the cells are not able to grow on solid media if for this they need to be in an activated physiological state.

Selective, or rather sequential, grazing is indicated by the successive population maxima and the different rates of population decline observed in the culture bags (Fig. 3 and 4). It seems logical that different cell sizes or species of flagellates may prefer different cell sizes or species of bacteria. Selective grazing may also be the reason for the short-lived CFU-maximum observed in all samples on March 28 when the AOTC were already declining. The doubling of populations by far exceeds the coefficient of variation between parallel samples.

Bacterial populations in the natural bag (Fig. 2) varied much less over time than populations in the fjord. Both ISTC and CFU varied extensively in the sea with exchanges in water masses and consequent variations in algal biomass and production and in dissolved organic carbon (Dahle and Laake, 1982). A sudden drop in temperature took place in the sea, from 4 to $5{ }^{\circ} \mathrm{C}$ on March 12 to less than $1{ }^{\circ} \mathrm{C}$ on March 20 , which in part may explain the termination of growth and cell reductions observed with the ISTC strains in the natural bag (Fig. 2). However, the ubiquitous presence of protozoans in the enrichment cultures for bdellovibrios suggest that protozoal grazing was the ecologically most important mechanism in regulation of population density also in the natural bag. 
The diversity of organotrophic bacteria was greatly reduced in periods of high substrate availability both in enclosed ecosystems (Fig. 6) and in the sea (Dahle and Laake, 1982) due to the growth and dominance of zymogenous species. Dahle and Laake (1982) reported a maximum $\mathrm{n}_{\text {AOTC }}=900$ before the onset of diatom growth, while the maximum observed at start in the natural bag was $n_{\text {AOTC }}=2900$. These figures are very high, and although not necessarily correct by number, still emphasize the very high numbers of serologically different strains of bacteria present in seawater. The 34 morphologically different strains isolated during the pre-study probably represented only a small fraction of the strains present. However, it is questionable to what extent these figures are directly comparable. The diversity indices observed in the natural bag are comparable to those observed in the fjord (Dahle and Laake, 1982), as were also the sizes of AOTC and CFU populations. This shows that enclosure of natural communities in plastic bags of $1 \mathrm{~m}$ diameter does not introduce serious artefacts.

Immunofluorescent staining depends on cultivation for vaccine production, which makes it impossible to test for a representative cross-section or an arbitrary selection of species from the total population (Dahle and Laake, 1982). Still, the simple diversity index we have used is believed to be of great value as an indication of the dynamic state of bacterial populations in a particular water body, e.g. during phytoplankton blooms, events of upwelling, or water exchange. The method itself is very convenient and easy to perform on large-scale sampling programs, when the anti-sera of relevance first have been made available. It is well known from medical microbiology that several serogroups may exist within 1 species (e.g. species of Streptococcus, Staphylococcus and Salmonella), and that these also may exhibit differences in pathogenicity. Marine bacteria serotype may be Iinked to differences of ecological significance, such as substrate affinity, metabolic capability, adherence to surfaces or production of exoenzymes. In conclusion, immunofluorescence is a powerful tool for elucidating the detailed functional and demographic structures of organotrophic bacteria in the sea, an important group that by other means is very difficult to study with acceptable resolution.

The small, vibroid and flagellated Bdellovibrio species are known to be obligate parasites on other bacteria and have been demonstrated in high numbers in the sea (Varon and Shilo, 1980). However, during this study no positive tests for Bdellovibrio were made. The rapid reductions in cells counted by different methods in the culture bags are thus not due to predatory bacteria. It does not seem very likely that the hostspectrum of these predators should be very different in
Rosfjord, compared to the sites from which the hostbacteria were isolated (Hentzschel, 1978).

Our inability to demonstrate presence of Bdellovibrio in Rosfjord can possibly be explained by the fact that most previous studies reporting high numbers have been conducted in waters polluted by domestic sewage, or in the summer season with temperatures of 15 to $20^{\circ} \mathrm{C}$ at the surface, while our observations were made in late winter. However, little is known about how environmental factors influence marine Bdellovibrios, and doubts have been raised as to the existence of this predator in nature outside of special ecological niches (Varon and Ziegler, 1978).

By measuring growth rate and biomass of the total bacterial population by direct methods in prefiltered seawater one arrives at realistic estimates of bacterial production (Fuhrman and Azam, 1980), although uncertainties exist in the average cell size used in calculations and in the representativity of measured growth rates. Higher than normal substrate concentrations may have resulted from the prefiltration procedure (Eberlein et al., 1983), which may have caused an overestimation of growth rates in the sea and in the natural bag (Table 3). When a dynamic steady state exists between growth of bacteria on renewed carbon sources and removal by grazing, i.e. by nanoflagellates, it seems reasonable to assume half-maximum growth rates also to prevail in natural systems, at least for the AOTC population. The bacterial populations were at almost the same level as in the culture bags, and the concentrations of dissolved carbohydrates and other substrates were lower but within the same order of magnitude (Eberlein et al., 1983).

The main uncertainty in the secondary production estimates is due to the average cell volumes used $\left(0.1 \mu \mathrm{m}^{3}\right)$ for conversion to biomass units. We did not systematically measure cell sizes by epifluorescence or other means (Fuhrman and Azam, 1980), but judging from AOTC microscopy the cells growing under rich substrate conditions (the situations chosen) were generally larger by length and diameter than cells present at low substrate pre-bloom conditions. The chosen value is somewhat less than the value $0.129 \mu \mathrm{m}^{3}$ recalculated from optimized yield factors for growth (Laake et al., 1983), but slightly larger than - or very near to the average cell volumes measured by other investigators for near-shore environments (Ferguson and Rublee, 1976; Watson et al., 1977; Hagström et al., 1979; Fuhrman and Azam, 1980). The calculated secondary production values are thus probably fairly correct or slightly overestimated.

A daily cycle was shown to exist in the concentrations of carbohydrates in the culture bags, suggesting the existence of a similar cycle in algal production of extracellular carbon and in bacterial decomposition 
(Eberlein et al., 1983). This was not confirmed in the bacterial data due to the time resolution used in observations, but cyclic changes in ammonia concentrations also suggest that such a coupling exists. However, Fuhrman et al. (1980) state that there is probably less of a direct coupling of bacterial secondary production to photosynthesis than to phytoplankton biomass. It is certainly also influenced by other factors. Estimates of 12 to $15 \%$ of net production demonstrates the significance of bacterial biomass as basis for production at higher trophic levels (Fuhrman and Azam, 1980). As discussed in more detail by Laake et al. (1983), bacteria-grazing nanoflagellates may represent an important link in the detrital food chain from bacteria to less efficient bacteria-grazers, like the larger ciliates and the microzooplankton. However, ecologically still more important may be the very high turnover of organic substances accomplished by the bacteria at the observed growth rates, as also evidenced by the culture bag data (Eberlein et al., 1983). Nanoflagellates and other bacterial grazers may, through regeneration of the bacterial biomass, be very important participants in these processes (Johannes, 1965).

Acknowledgements. This work was supported by the Norwegian Marine Pollution Research and Monitoring Programme, contract FOH 405 (Laake and Dahle), and by the Deutsche Forschungsgemeinschaft' through the 'Sonderforschungsbereich 94 - Meeresforschung Hamburg' (Hentzschel). Dr. U. $\mathrm{H}$. Brockmann is acknowledged for his valuable comments on the manuscript, and C. C. Price for linguistic improvements.

\section{LITERATURE CITED}

Banse, K. (1974). On the role of bacterioplankton in the tropical oceans. Mar. Biol. 24: 1-5

Bell, W. H., Lang, J. M., Mitchell, R. (1974). Selective stimulation of marine bacteria by algal extracellular products. Limnol. Oceanogr. 19: 833-839

Bell, W. H., Sakshaug, E. (1980). Bacterial utilization of algal extracellular products. II. A kinetic study on natural populations: The phycoshaere effect. Limnol. Oceanogr. 25: 1021-1033

Brockmann, U. H., Eberlein, K., Junge, H. D., Trageser, H., Thrams, K. J. (1974). Einfache Folientanks zur Planktomuntersuchung in situ. Mar. Biol. 24: 163-166

Brockmann, U. H., Koltermann, K. P., Dahl, E., Dahle, A. B., Eberlein, K., Gaertner, A., Gassmann, G., Hammer, K. D., Jahnke, J., Kattner, G., Krause, M., Kuiper, J., Laake, M., Nagel, K. (1981). Water exchange in Rosfjorden during spring '79, a detailed account of physical, chemical and biological variations. In: Saetre, R, Mork, M. (ed.) The Norwegian coastal current, Vol. 1. University of Bergen, Bergen, p. 93-130

Buchanan, R. E., Gibbons, N. E. (1974). Bergey's manual of determinative bacteriology, 8th ed. The Williams \& Wilkins, Company, Baltimore

Dahl, E., Laake, M., Tjessem, K., Eberlein, K., Bøhle, B. (1983). Effects of Ekofisk crude oil on an enclosed planktonic ecosystem. Mar Ecol. Prog. Ser. 14: 81-91
Dahle, A. B., Laake, M. (1982). Diversity dynamics of marine bacteria studied by immunofluorescent staining on membrane filters. Appl. environ. Microbiol. 43: 169-176

Eberlein, K., Brockmann, U. H., Hammer, K. D., Kattner, G., Laake, M. (1983). Total dissolved carbohydrates in an enclosure experiment with unialgal Skeletonema costatunn culture. Mar. Ecol. Prog. Ser. 14: 45-58

Ferguson, R. L., Rublee, P. (1976). Contribution of bacteria to the standing crop of coastal plankton. Limnol. Oceanogr. 21: $141-145$

Fuhrman, J. A., Ammerman, J. W., Azam, F. (1980). Bacterioplankton in the coastal euphotic zone: distribution, activity and possible relationships with phytoplankton. Mar. Biol. 60: 201-207

Fuhrman, J. A., Azam, F. (1980). Bacterioplankton secondary production estimates for coastal waters of British Columbia, Antarctica and California. Appl. environ. Microbiol. 39: $1085-1095$

Hagström, §., Larsson, U., Hørstedt, P., Normark, S. (1979). Frequency of dividing cells, a new approach to the determination of bacterial growth rates in aquatic environments. Appl. environ. Microbiol. 37: 805-812

Hentzschel, G. (1978). Host range studies to the classification of marine Bdellovibrio strains. Mitt. Inst. allg. Bot., Hamb. 16: $135-145$

Hentzschel, G. (1980). Interactions between bacteriolytic and saprophytic bacteria from the North Sea. Mitt. Inst. allg. Bot., Hamb. 17: 113-124

Hobbie, J. E., Daley, R. J., Jasper, S. (1977). Use of Nuclepore filters for counting bacteria by fluorescence microscopy. Appl. environ. Microbiol. 33: 1225-1228

Jahnke, J., Brockmann, U. H., Aletsee, L., Hammer, K. D. (1983). Phytoplankton activity in enclosed and free marine ecosystems in a southern Norwegian fjord during spring 1979. Mar. Ecol. Prog. Ser. 14: 19-28

Johannes, R. E. (1965). The influence of marine protozoa on nutrient regeneration. Limnol. Oceanogr. 10: 434-442

Laake, M., Dahle, A. B., Eberlein, K., Rein, K. (1983). A modelling approach to the interplay of carbohydrates, bacteria and non-pigmented flagellates in a controlled ecosystem experiment with Skeletonema costatum. Mar. Ecol. Progr. Ser, 14: 71-79

Meyer-Reil, L.-A., Bölter, M., Liebezeit, G., Schramm, W. (1979). Shortterm variations in microbiological and chemical parameters. Mar. Ecol. Prog. Ser. 1: 1-6

Overbeck, J., Daley, R. J. (1973). Some precautionary comments on the Romanenko technique for estimating heterotrophic bacterial production. Bull. Ecol. Res. Comm. Natl. Sci. Res. Counc. 17: 342-344

Sieburth, J. McN. (1979). Sea microbes. Oxford University Press, New York

Sorokin, Y. I. (1971). On the role of bacteria in the productivity of tropical ocean waters. Int. Revue ges. Hydrobiol. 56: $1-48$

Varon, M., Shilo, M. (1980). Ecology of aquatic bdellovibrios. In: Droop, M. R, Jannasch, H. W. (ed.) Advances in aquatic microbiology, Vol. II. Academic Press, New York, p. $1-48$

Varon, M., Ziegler, B. P. (1978). Bacterial predator-prey interaction at low prey density. Appl. environ. Microbiol. 36: $11-17$

Watson, S. W., Novitsky, T. J., Quinby, H. L., Valois, F. W. (1977). Determination of bacterial number and biomass in the marine environment. Appl. environ. Microbiol. 33: $940-946$ 